\title{
Life Cycle Assessment for Supporting Eco-Design: The Case Study of Sodium-Nickel Chloride Cells
}

\author{
Sonia Longo ${ }^{1, *(\mathbb{D}}$, Maurizio Cellura ${ }^{1,2}$, Maria Anna Cusenza ${ }^{1}$, Francesco Guarino ${ }^{1}$, Marina Mistretta ${ }^{3}(\mathbb{D}$, \\ Domenico Panno ${ }^{1}\left(\mathbb{D}\right.$, Claudia D’Urso $^{2}$, Salvatore Gianluca Leonardi ${ }^{2}{ }^{\circ}$, Nicola Briguglio ${ }^{2}$, Giovanni Tumminia ${ }^{2}$, \\ Vincenzo Antonucci ${ }^{2}$ and Marco Ferraro ${ }^{2}$ \\ 1 Dipartimento di Ingegneria, Università degli Studi di Palermo, Viale delle Scienze Ed.9, 90128 Palermo, Italy; \\ maurizio.cellura@unipa.it (M.C.); mariaanna.cusenza@unipa.it (M.A.C.); francesco.guarino@unipa.it (F.G.); \\ domenico.panno@unipa.it (D.P.) \\ 2 Consiglio Nazionale delle Ricerche Istituto di Tecnologie Avanzate per 1'Energia "Nicola Giordano", Via S. \\ Lucia sopra Contesse, 5, 98126 Messina, Italy; durso@itae.cnr.it (C.D.); leonardi@itae.cnr.it (S.G.L.); \\ briguglio@itae.cnr.it (N.B.); tumminia@itae.cnr.it (G.T.); antonucci@itae.cnr.it (V.A.); ferraro@itae.cnr.it (M.F.) \\ 3 Dipartimento di Patrimonio, Architettura e Urbanistica, Università degli Studi Mediterranea di Reggio \\ Calabria, Salita Melissari, 89124 Reggio Calabria, Italy; marina.mistretta@unirc.it \\ * Correspondence: sonia.longo@unipa.it
}

check for

updates

Citation: Longo, S.; Cellura, M.; Cusenza, M.A.; Guarino, F.; Mistretta, M.; Panno, D.; D’Urso, C.; Leonardi, S.G.; Briguglio, N.; Tumminia, G.; et al. Life Cycle Assessment for Supporting Eco-Design: The Case Study of Sodium-Nickel Chloride Cells. Energies 2021, 14, 1897. https://doi.org/10.3390/en14071897

Academic Editor: Sergio Ulgiati

Received: 8 March 2021

Accepted: 26 March 2021

Published: 30 March 2021

Publisher's Note: MDPI stays neutral with regard to jurisdictional claims in published maps and institutional affiliations.

Copyright: (C) 2021 by the authors Licensee MDPI, Basel, Switzerland. This article is an open access article distributed under the terms and conditions of the Creative Commons Attribution (CC BY) license (https:/ / creativecommons.org/licenses/by/ $4.0 /)$.

\begin{abstract}
The European Union is moving towards a sustainable, decarbonized, and circular economy. It has identified seven key value chains in which to intervene, with the battery and vehicle value chain being one of them. Thus, actions and strategies for the sustainability of batteries need to be developed. Since Life Cycle Assessment (LCA) is a strategic tool for evaluating environmental sustainability, this paper investigates its application to two configurations of a sodium-nickel chloride cell (planar and tubular), focusing on the active material and the anode, with the purpose of identifying the configuration characterized by the lowest environmental impacts. The results, based on a "from cradle to gate" approach, showed that the tubular cell performs better for all environmental impact categories measured except for particulate matter, acidification, and resource depletion. With nickel being the main contributor to these impact categories, future sustainable strategies need to be oriented towards the reduction/recovery of this material or the use of nickel coming from a more sustainable supply chain. The original contribution of the paper is twofold: (1) It enriches the number of case studies of LCAs applied to sodium/nickel chloride cells, adding to the few studies on these types of cells that can be found in the existing scientific literature. (2) The results identify the environmental hot spots (cell configuration and materials used) for improving the environmental footprint of batteries made from sodium/nickel chloride cells.
\end{abstract}

Keywords: life cycle assessment; environmental impact; sodium-nickel chloride cells; environmental sustainability

\section{Introduction}

The design of products and technologies is at the heart of sustainability, enabling the identification of a product's configurations and materials characterized by lower environmental impacts. The design of a product can influence its lifespan, reparability, recyclability, and the content of recycled materials, as well as the supply chains of the input materials and the possibility to regenerate the product [1].

The design process is a complex task that must take into account technical, energy, environmental, and economic factors. Eco-efficiency and eco-design are central requirements for creating sustainable and circular products, reducing resource and material mass flows per product or service, and dealing with global environmental problems [2].

Products with a high potential for supporting the transition towards a more sustainable economy should be identified in order to correctly orient future strategies, priorities, 
and investments. The European Commission, in its recent communication on the circular economy, identified batteries and vehicles as one of the seven key value chains for supporting this transition [3]. Thus, actions and strategies need to be defined and adopted to move batteries and vehicles towards sustainable growth models.

Particular attention must be paid to the eco-design of batteries, not only in order to follow general circular and sustainable principles, but also to deliver products manufactured with fewer, renewable, recyclable/recycled, and non-hazardous materials and characterized by lower energy and environmental impacts during their life cycle.

Moreover, as outlined in the European Directive on batteries and accumulators and waste batteries and accumulators [4], the eco-efficiency and environmental impact reduction of batteries during their whole life cycle, the manufacturing of storage systems containing small quantities of dangerous and polluting substances, and the promotion of secure and low-impact raw materials are also key elements of sustainability.

The role of batteries in the decarbonization process highlights the need to support the growth of a cell manufacturing industry with the smallest environmental footprint possible, as specified by the European Battery Alliance [5].

The environmental sustainability of the battery sector is of growing interest in Europe, and its importance is supported by the fact that electrification is set to be one of the main technological pathways to reach carbon neutrality, with batteries being key enablers of this process [6]. Energy storage systems also support the balance of an electric power system with a high penetration of time-varying renewable resources [7].

The manufacturing of low-impact products starts with the consideration that all materials have "embodied" environmental impacts during their life cycle, from the raw material supply to end-of-life. These environmental impacts have to be identified by following a Life Cycle Thinking (LCT) approach, which means looking at its whole life cycle and taking into account all the environmental aspects (raw material consumption and emissions into air, water, and soil). The LCT approach can identify production strategies that are able to reduce negative environmental effects.

Considering that more than $80 \%$ of the impacts of products are caused by choices made during the design phase [8], this step has a primary role in favoring the diffusion onto the market of more sustainable and circular products. The evaluation of the environmental criticalities due to different design options requires the quantification of the life cycle environmental burdens/benefits due to these options/strategies [9].

Life Cycle Assessment (LCA) is a reliable methodology for use in eco-design choices. It allows for the calculation of the energy and environmental impacts of products and systems in terms of raw material consumption, and air, water, and soil emissions. Moreover, it can focus on the direct impacts generated during the manufacturing or use of a product or system, the hidden impacts related to the supply chains of input materials and energy sources, and the life cycle steps generally neglected such as installation or end-of-life [10,11].

LCA studies of different electricity storage systems have been carried out in the scientific literature, giving an overview of their energy and environmental impacts and identifying the key issues to be examined in depth for reducing these impacts.

Two important aspects emerge from these studies, as highlighted by [12-14]:

- $\quad$ Few studies are based on detailed data for the foreground processes. Thus, even if the topic of LCA of batteries has already been discussed in the literature, further research is needed on specific parts/components and processes related to batteries in order to gain more knowledge in this field;

- The comparison of studies is often a difficult task, due to different methodological assumptions (e.g., functional units, system boundaries, cut-off rules, uncertainty of secondary data, variation in primary data, etc.) and battery features (e.g., cathode and anode composition, battery application, etc.).

Despite the difficulty of comparison, a range of values can be extrapolated from studies for some indicators. In detail, the global energy requirement can vary from $17 \mathrm{MJ} / \mathrm{kg}$ of battery (Pb-acid battery and from cradle to gate approach) [15] to about $566 \mathrm{MJ} / \mathrm{kg}$ of 
battery (Li-ion battery and from cradle to grave approach) [16], while global warming potential has a range from $0.9 \mathrm{~kg} \mathrm{CO} \mathrm{CO}_{2 \mathrm{eq}} / \mathrm{kg}$ of battery $(\mathrm{Pb}$-acid battery and from cradle to gate approach) [15] to about $55 \mathrm{~kg} \mathrm{CO}{ }_{2 \mathrm{eq}} / \mathrm{kg}$ of battery (nickel-metal hydride battery and from cradle to grave approach) [16] or from about $53 \mathrm{~kg} \mathrm{CO}_{2 \mathrm{eq}} / \mathrm{kWh}$ of battery energy capacity (Li-ion battery and from cradle to grave approach) [17] to about $490 \mathrm{~kg} \mathrm{CO}_{2 \mathrm{eq}} / \mathrm{kWh}$ of battery energy capacity (Li-ion battery and from cradle to gate approach) [18].

An analysis of these results is useful for identifying the components/materials responsible for greater impacts, and this should be considered when developing eco-design processes. To this purpose, Longo et al. [13] identified nickel powder as being responsible for most of the impacts caused by a sodium nickel chloride cell, with a variation from $33 \%$ for human toxicity to about 70\% for acidification. According to Cusenza et al. [12], the anode production causes about $66 \%$ of the impact on abiotic depletion potential for a lithium-ion cell, while the anode and cathode production cause more than $50 \%$ of the impact on human toxicity, marine and freshwater eutrophication, and freshwater ecotoxicity. Majeau-Bettez et al. [19] calculated that mining and metallurgy activities for nickel used in the electrodes and current collectors are responsible for more than $70 \%$ of toxicity and ecotoxicity and more than $80 \%$ of particulate matter, terrestrial acidification, and metal depletion.

As stated before, one of the current issues for batteries is the reduction of their life cycle energy and environmental impacts focusing on the use of small quantities of and/or low-impact raw materials that are also recyclable or recycled. This paper aims to support the research in this field by examining the environmental aspects of design options for sodium-nickel chloride cells. This cell typology was selected for two main reasons:

- Sodium-nickel chloride batteries are innovative storage systems used both in mobile and stationary applications $[20,21]$. They are characterized by a broad range of operating temperatures $\left(-20^{\circ} \mathrm{C}-+60^{\circ} \mathrm{C}\right)$ without the need for complex thermal management systems, which makes them suitable for extreme cold or hot environments. In addition, these batteries do not require maintenance and are fully recyclable [22].

- While most of the LCAs of storage systems examined lithium-ion batteries, very few studies have looked at the LCAs of sodium-nickel chloride batteries $[13,23,24]$. Thus, the topic is worthy of investigation.

Furthermore, even if some studies have been performed to compare design options of sodium-nickel chloride batteries [25-28], focusing on the power delivered from batteries with planar or tubular shapes, on the quantity of materials used, on the operative conditions, costs, etc., a complete and reliable comparison must also include the environmental aspect of materials supply from a life cycle perspective. To the authors' knowledge, only limited literature is available on this topic for the abovementioned battery typology $[13,23,24]$, as outlined above.

In this context, the study shows the results of the application of an LCA with the aim of selecting the most sustainable configuration for a sodium-nickel chloride cell and identifying solutions aimed at improving the environmental performances of the cells. The results of the study could be useful to researchers and designers in the field who require data on the environmental performances of these technologies.

\section{LCA of Sodium-Nickel Chloride Cells}

\subsection{Goal and Scope Definition}

The goal of the analysis is to apply the life cycle perspective to a sodium-nickel chloride cell in order to identify the shape of the cell (tubular or planar) characterized by lower energy and environmental impacts. In detail, a tubular cell was compared with a planar one by applying the LCA methodology, according to the International Standards of the ISO 14040 series [10,11].

The analysis focuses on identifying the life cycle impacts caused by the inputs of the two examined cells, which use the same materials for their cathodes, electrolytes, and anodes but in different amounts. Thus, the system boundaries, representing the unit 
processes involved in the study, are selected following a "from cradle to gate" approach and include the raw materials supply and the manufacturing processes of the main input materials used for the cathode, electrolyte, and anode production. The other parts of the cell are not included in the assessment. Focusing on the case of the cell, even if both configurations have different shapes that lead to different material consumptions, previous research [13] points out that the cell case gives a contribution of less than $2 \%$ of the total cell impacts, except for human toxicity which is less than $10 \%$. For this reason, this item was neglected in the analysis.

Furthermore, due to the selected system boundaries, the operation and end-of-life are excluded from the analysis.

The function of a cell is to store and release energy. A characteristic of the cell, measuring the electric charge that can be accumulated during the charge, stored during the open circuit stay, and released during the discharge, is the cell capacity [29], which can also be defined as the maximum amount of energy that can be extracted from the cell under certain specified conditions [30]. The cell capacity, measured in amperes per hour (Ah), can describe the potential performance of a cell without considering the operative conditions. In this study, the life cycle energy and environmental performances of the two examined cells are compared to a reference cell with a capacity of $1 \mathrm{Ah}$, selected as a functional unit (according to ISO 14040, the functional unit is the quantified performance of a product system for use as a reference unit [10]).

It was assumed that the cells had the same lifespan. Charge/discharge efficiency was calculated during electrochemical tests and was about $94 \%$ for both configurations (this value is in accordance with other studies $[28,31,32])$.

The energy and environmental aspects of the examined cells are synthesized by using indexes (Table 1) describing the raw material consumption (with and without energy content) and environmental impacts. The aggregation is based on the characterization factors of the cumulative energy demand method [33] for primary energy and of the ILCD 2011 Midpoint+ method [34] for the environmental impacts.

Table 1. Energy and environmental indexes.

\begin{tabular}{|c|c|c|}
\hline Impact Category & Acronym & Unit of Measure \\
\hline Global Energy Requirement & GER & MJ \\
\hline Global Energy Requirement-non-renewable & GER-nr & MJ \\
\hline Global Energy Requirement-renewable & GER-r & MJ \\
\hline Global Warming Potential & GWP & $\mathrm{kgCO}_{2 \mathrm{eq}}$ \\
\hline Ozone Depletion Potential & ODP & $\mathrm{kgCFC}-11_{\mathrm{eq}}$ \\
\hline Human Toxicity-Cancer effects & HT-c & CTUh \\
\hline Human Toxicity-Non-cancer effects & HT-nc & CTUh \\
\hline Particulate Matter & PM & $\mathrm{kg}$ PM2.5 $\mathrm{eq}_{\mathrm{eq}}$ \\
\hline Ionizing Radiations $\mathrm{HH}$ & IR-HH & $\mathrm{kBq} U 235_{\mathrm{eq}}$ \\
\hline Ionizing Radiations E & IR-E & CTUe \\
\hline Photochemical Ozone Formation & POF & $\mathrm{kg} \mathrm{NMVOC}$ eq \\
\hline Acidification & Ac & molc $\mathrm{H}^{+}$eq \\
\hline Terrestrial Eutrophication & $\mathrm{TE}$ & molc $\mathrm{N}_{\mathrm{eq}}$ \\
\hline Freshwater Eutrophication & FE & $\mathrm{kg} \mathrm{P}$ eq \\
\hline Marine Eutrophication & ME & $\mathrm{kg} \mathrm{N}$ eq \\
\hline Freshwater Ecotoxicity & FET & CTUe \\
\hline Land Use & LU & $\mathrm{kg} \mathrm{C}$ deficit \\
\hline Water Depletion & WD & $\mathrm{m}^{3}$ water $_{\mathrm{eq}}$ \\
\hline Resource Depletion-mineral, fossil, renewable & RD & $\mathrm{kg} \mathrm{Sb}_{\text {eq }}$ \\
\hline
\end{tabular}

\subsection{Primary and Secondary Data}

The application of LCA is usually based on primary and secondary data. Primary data identify the materials and energy sources used for the product manufacturing (foreground process) and are directly collected in situ (laboratories for lab-scale analyses or manufacturing firms for commercial products); secondary data describe the impacts of 
the materials and energy source supply chains (background processes) and come from environmental databases or sectorial studies.

In this application, primary data are derived from experimental analyses of cell prototypes carried out by authors, while secondary data are from the environmental database Ecoinvent [35].

The cell components include: the negative electrode (anode) made from sodium; the positive electrode (cathode) consisting of nickel, sodium chloride $(\mathrm{NaCl})$, and additives (aluminum, sodium iodide (NaI), sodium fluoride $(\mathrm{NaF})$ and iron sulfide $(\mathrm{FeS})$ ) mixed with a secondary sodium tetrachloroaluminate $(\mathrm{NaAlCl} 4)$ electrolyte; the solid $\beta$-alumina electrolyte.

The two cells, characterized by the same lifespan and charge/discharge efficiency, have different capacities: the planar cell has a capacity of $157 \mathrm{mAh}$ with a charge/discharge current $(\mathrm{C} / 2)$ of $78.5 \mathrm{~mA}$; the tubular cell has a capacity of $32 \mathrm{Ah}$ with a charge/discharge current $(\mathrm{C} / 2)$ of $16 \mathrm{~A}$. A different capacity implies a diverse amount of inputs for the two cells when the data are compared to the same functional unit.

Table 2 shows the materials (chemical elements) used for the planar and tubular cell manufacturing (primary data) for 1 Ah of cell capacity, while the processes selected for modeling secondary data are reported in Table 3.

Table 2. Materials used for the cell manufacturing (data refer to 1 Ah of cell capacity).

\begin{tabular}{ccc}
\hline Material & Planar Cell (kg/Ah) & Tubular Cell (kg/Ah) \\
\hline Sodium (Na) & $1.65 \times 10^{-3}$ & $3.22 \times 10^{-3}$ \\
Nickel (Ni) & $3.96 \times 10^{-3}$ & $4.03 \times 10^{-3}$ \\
Chlorine (Cl) & $6.05 \times 10^{-3}$ & $4.38 \times 10^{-3}$ \\
Aluminum (Al) & $9.30 \times 10^{-4}$ & $5.81 \times 10^{-4}$ \\
Iron (Fe) & $5.10 \times 10^{-5}$ & $2.50 \times 10^{-4}$ \\
Iodine (I) & $2.70 \times 10^{-5}$ & $1.97 \times 10^{-4}$ \\
Fluorine (F) & $2.61 \times 10^{-5}$ & $1.90 \times 10^{-4}$ \\
Sulfur (S) & $5.10 \times 10^{-5}$ & $3.71 \times 10^{-4}$ \\
B-alumina & $1.18 \times 10^{-2}$ & $4.06 \times 10^{-3}$ \\
Total & $2.46 \times 10^{-2}$ & $1.73 \times 10^{-2}$
\end{tabular}

Table 3. Secondary data for modeling the background processes.

\begin{tabular}{cc}
\hline Input & Process Name \\
$\mathrm{Na}$ & Adapted from sodium chloride, powder, at plant \\
$\mathrm{Ni}$ & Nickel, $99.5 \%$, at plant \\
$\mathrm{Cl}$ & Chlorine, liquid, production mix, at plant \\
$\mathrm{Al}$ & Aluminum, primary, at plant \\
$\mathrm{Fe}$ & Iron ore, $46 \%$ Fe, at mine \\
$\mathrm{I}$ & Adapted from sodium chlorine, brine solution, at plant \\
$\mathrm{F}$ & Fluorine, liquid, at plant \\
$\mathrm{S}$ & Secondary sulfur, at refinery \\
$\beta$-alumina & Aluminum oxide, at plant \\
\hline
\end{tabular}

The chemical elements were calculated starting from the composition of each component (cathode, anode, and electrolytes), by using the molecular weight and the weight of the atomic masses.

The manufacturing of the anode, cathode, and electrolyte from raw materials was carried out manually in the laboratory.

The background data of the input supply chains refer to the European context, except for nickel and iron (global context).

Due to a lack of secondary data, the processes for iodine and sodium were modeled starting from processes for sodium chloride brine solution and sodium chloride powder, respectively. 
The above data indicate that the planar cell needs more inputs (about $42 \%$ ) than the tubular one to obtain a cell capacity of $1 \mathrm{Ah}$. The above difference is mainly due to the in-put of $\beta$-alumina (one order of magnitude higher in the planar cell), chlorine, and aluminum ( $38 \%$ and $60 \%$ higher, respectively). Regarding the other materials, the tubular cell requires more inputs. For iron, iodine, fluorine, and sulfur, there are differences of one order of magnitude, while the consumption of sodium and nickel is higher by about $95.4 \%$ and $1.6 \%$, respectively.

\section{Results and Discussion}

Primary and secondary data were elaborated for calculating environmental indicators describing the eco-profile of the two cells in terms of raw material consumption, and air, water, and soil emissions. Then, the above indicators were grouped into the energy and environmental indexes defined in Table 1.

Focusing on the life cycle energy performances (Figure 1), lower impacts are caused by the tubular configuration (1.3 MJ for planar cell versus 1.1 MJ for tubular cell). For both configurations, more than $82.5 \%$ of the total primary energy consumption arises from non-renewable sources.

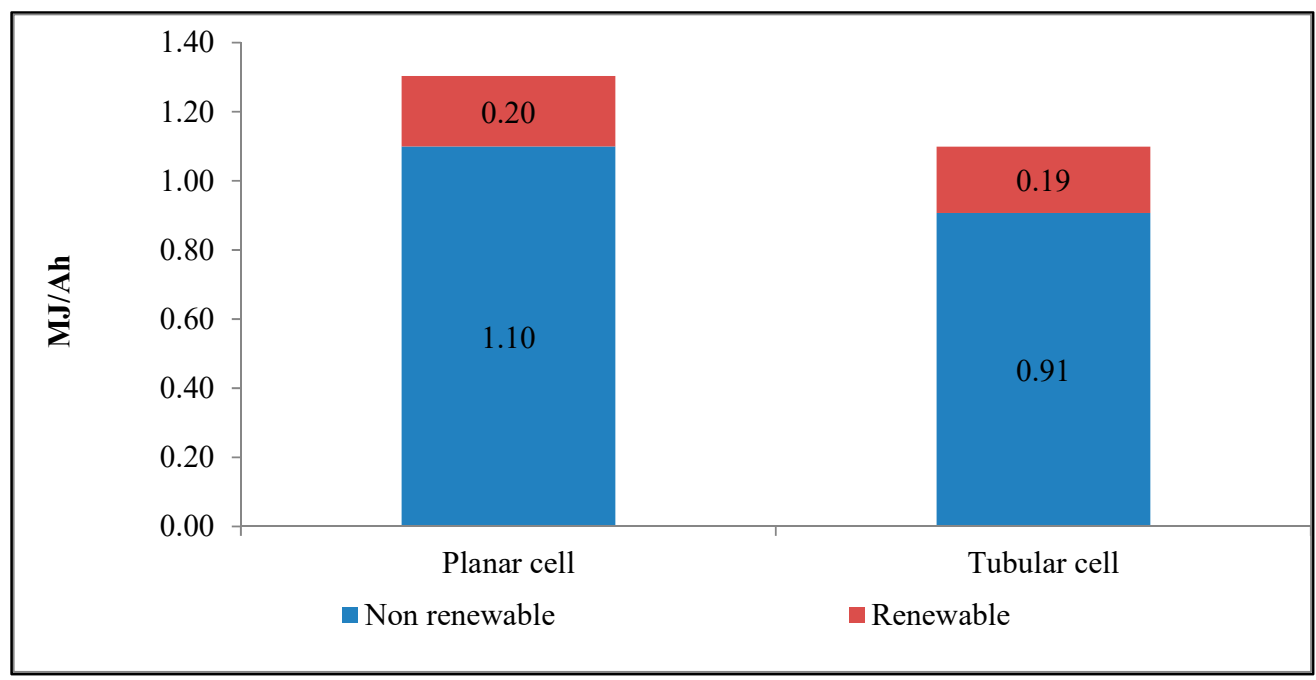

Figure 1. Cumulative energy demand of the two cell configurations (data for $1 \mathrm{Ah}$ ).

Nickel is the most energy-intensive material. It requires $57.2 \%$ of total primary energy for the planar cell and $68.6 \%$ for the tubular one. $\beta$-alumina is responsible for about $7.2 \%$ of total primary energy for the tubular cell and $17.7 \%$ for the planar cell, while a contribution varying from about $9 \%$ to $14 \%$ is due to chlorine and aluminum for both configurations. A negligible contribution is provided by other materials.

Focusing on the environmental impacts (Table 4), the results reveal that the tubular cell performs better for most of the environmental impact categories except for particulate matter, acidification, and resource depletion. To be more precise, the percentage reduction varies from $1.46 \%$ (freshwater eutrophication) to $38.3 \%$ (human toxicity-cancer effect). 
Table 4. Environmental impacts of the two examined configurations (data for $1 \mathrm{Ah}$ ).

\begin{tabular}{|c|c|c|c|}
\hline Impact Category & Unit & Planar Cell & Tubular Cell \\
\hline GWP & $\mathrm{kgCO}_{2 \mathrm{eq}}$ & $7.60 \times 10^{-2}$ & $6.34 \times 10^{-2}$ \\
\hline ODP & $\mathrm{kg} \mathrm{CFC}-11_{\mathrm{eq}}$ & $1.63 \times 10^{-8}$ & $1.22 \times 10^{-8}$ \\
\hline HT-c & CTUh & $2.66 \times 10^{-7}$ & $2.62 \times 10^{-7}$ \\
\hline HT-nc & CTUh & $3.22 \times 10^{-8}$ & $1.99 \times 10^{-8}$ \\
\hline PM & $\mathrm{kg}$ PM2.5eq & $3.99 \times 10^{-4}$ & $4.01 \times 10^{-4}$ \\
\hline IR-HH & $\mathrm{kBq} U 235_{\mathrm{eq}}$ & $2.05 \times 10^{-2}$ & $1.83 \times 10^{-2}$ \\
\hline IR-E & CTUe & $6.31 \times 10^{-8}$ & $5.64 \times 10^{-8}$ \\
\hline POF & $\mathrm{kg} \mathrm{NMVOC}$ eq & $8.49 \times 10^{-4}$ & $8.20 \times 10^{-4}$ \\
\hline Ac & molc $\mathrm{H}^{+}{ }_{\text {eq }}$ & $7.66 \times 10^{-3}$ & $7.74 \times 10^{-3}$ \\
\hline TE & molc $\mathrm{N}_{\mathrm{eq}}$ & $1.85 \times 10^{-3}$ & $1.72 \times 10^{-3}$ \\
\hline FE & $\mathrm{kg} \mathrm{P}_{\mathrm{eq}}$ & $1.75 \times 10^{-4}$ & $1.73 \times 10^{-4}$ \\
\hline $\mathrm{ME}$ & $\mathrm{kg} \mathrm{N}_{\mathrm{eq}}$ & $1.47 \times 10^{-4}$ & $1.35 \times 10^{-4}$ \\
\hline FET & CTUe & 7.26 & 6.93 \\
\hline LU & $\operatorname{kg} C$ deficit & $1.43 \times 10^{-1}$ & $1.22 \times 10^{-1}$ \\
\hline WD & $\mathrm{m}^{3}$ water $_{\mathrm{eq}}$ & $4.48 \times 10^{-4}$ & $4.02 \times 10^{-4}$ \\
\hline $\mathrm{RD}$ & $\mathrm{kg} \mathrm{Sb}$ eq & $2.19 \times 10^{-5}$ & $2.35 \times 10^{-5}$ \\
\hline
\end{tabular}

The obtained results suggest the use of the tubular shape of the cell instead of the planar one, particularly if focusing on the impact categories of human toxicity-cancer effect, ozone depletion, and climate change, for which differences greater than $16 \%$ are observed.

However, for obtaining a tubular cell more sustainable than the planar one for all the examined environmental aspects, eco-design processes should focus on actions aimed at reducing the impacts on $\mathrm{PM}, \mathrm{Ac}$, and $\mathrm{RD}$, which are higher for the tubular cell by about $0.5 \%, 1.1 \%$, and $7.4 \%$, respectively. Looking at these differences, which are negligible, reveals that obtaining a more sustainable tubular cell does not require great effort.

A dominance analysis was carried out for identifying the components responsible for the main impacts. As shown in Figure 2, for the planar cell, the main contributor to the impacts is nickel, the contribution of which varies from $50.3 \%$ (ionizing radiations, $\mathrm{HH}$ ) to $97.5 \%$ (acidification); only for ozone depletion and human toxicity-cancer effect is the contribution lower than this (20.9\% and $34.2 \%$, respectively). Ozone depletion is mainly caused by chlorine (about $63.5 \%$ ), which is also responsible for about $22.5 \%$ of ionizing radiations, $25 \%$ of resource depletion, and $8.4 \%$ of global warming; its incidence in the other remaining impact categories is lower than $4.2 \%$. In addition, $53.9 \%$ of the impact on human toxicity-cancer effect is caused by $\beta$-alumina, which also causes about $19-20 \%$ of the impacts on global warming and land use, and about $10-12 \%$ of the impact on ionizing radiations, ozone depletion, and terrestrial and water eutrophication. A contribution lower than $9 \%$ is traced to the other impact categories.

Aluminum has a share of the impacts ranging from $0.4 \%$ (resource depletion) to $15 \%$ (global warming), while the contribution of the remaining cell materials is lower than $1 \%$.

The dominance analysis for the tubular cells is represented in Figure 3. In this case, also, nickel causes most of the impacts, with a percentage that varies from $56.4 \%$ (human toxicity-cancer effect) to $98 \%$ (acidification), except for ozone depletion, where nickel accounts for about $28.4 \%$ of the impact. Chlorine is responsible for $61.5 \%$ of ozone depletion, $20.2 \%$ of water depletion, $18.3 \%$ of ionizing radiations and $7.3 \%$ of global warming, and has an incidence lower than $3.3 \%$ in the other impact categories. Aluminum causes about $10-11 \%$ of global warming, ionizing radiation, and human toxicity - cancer effect, about $6 \%$ of land use and water depletion, and gives a contribution lower than $4 \%$ to the remaining impact categories. 


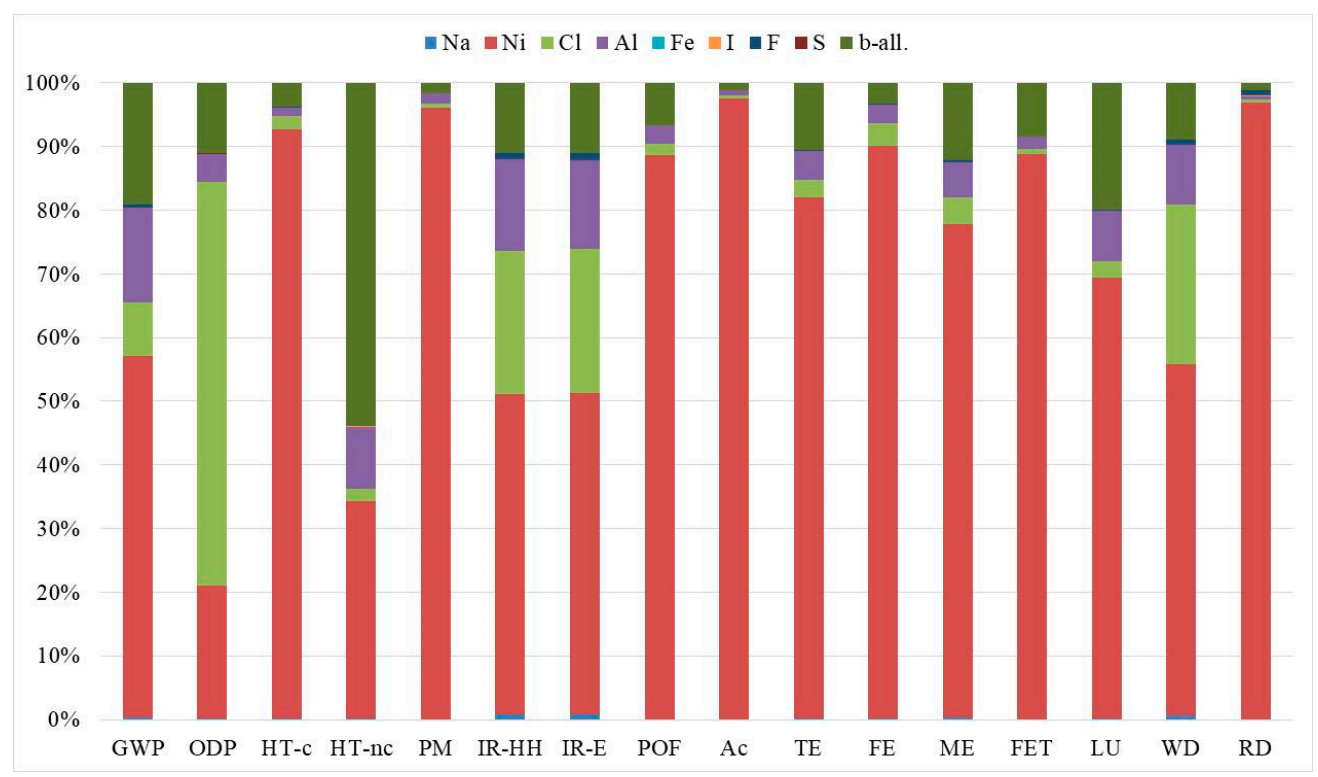

Figure 2. Environmental impacts of the planar cell: dominance analysis.

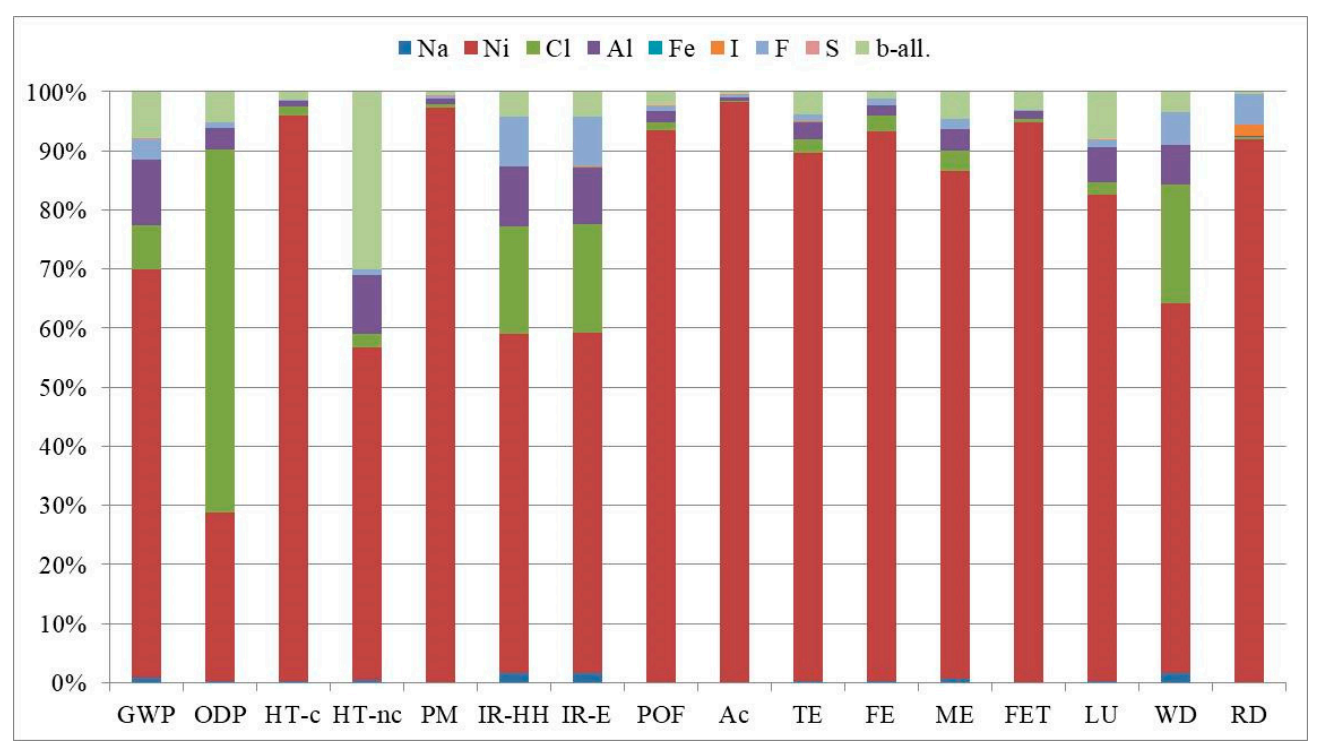

Figure 3. Environmental impacts of the tubular cell: dominance analysis (percentage incidence).

$\beta$-alumina causes about $30 \%$ and $7.9 \%$ of the impact on human toxicity-cancer effect, and global warming and land use, respectively, while its contribution to the other impacts is lower than $5 \%$.

Fluorine contributes about $8 \%$ and $5 \%$ towards the impact on ionizing radiations and resource and water depletion, respectively. Impacts lower than $3.4 \%$ are caused for the other impact categories. Sodium, iron, iodine, and sulfur have an incidence lower than $2 \%$ on the overall impacts.

Considering that nickel is a critical material for many impact categories for both the tubular and planar cells, low-impact nickel supply chains, along with its recovery from exhaust batteries, should be supported. Although refining nickel requires high-precision technologies for selecting, extracting, and refining, this option is viable for obtaining nickel for second life use in another battery as part of so-called "battery to battery" recycling [36]. Using nickel in its second life could have a double advantage: from one side, it can reduce the impacts of batteries (LCA studies on the recovery process should be developed to 
demonstrate this) and from the other side, it reduces the dependency of battery industries on imported virgin material that may be subject to price volatility [37].

\section{Conclusions}

This research aims to examine eco-design options, in terms of materials and technological solutions, for battery cells. Two different configurations for a sodium-nickel chloride cell were analyzed, in which different quantities of the active material (cathode and electrolyte) and anode are used. The application of LCA points out that, while selecting $1 \mathrm{Ah}$ as the functional unit, most of the energy and environmental impacts of the tubular cell are lower than those of the planar cell, with a percentage variation of between $1.5 \%$ to about $38 \%$. This result supports the choice of a tubular shape for the cells, even if three out of 16 impact categories have worse values for this solution (particulate matter, acidification, and resource depletion). However, whenever the planar cell performs better, differences lower than $7.5 \%$ are observed. This result suggests a first eco-design option: to prefer a tubular configuration instead of a planar one, in particular when the focus is on human toxicity-cancer effect, ozone depletion, and climate change (where differences between the impacts were greater than $16 \%$ ). The application of this eco-design option does not influence the typology of materials used in the cell and their respective supply chains, but only the relative quantities: the mass of $\beta$-alumina, chlorine and aluminum decreases in the tubular cell while the mass of the other materials increases. Considering that the above changes can have an effect on the production price of the cell, an economic evaluation is suggested. Furthermore, small differences between tubular and planar cells could be observed in the cell case manufacturing process, considering that the case has a different shape in the two examined options.

Focusing on each cell configuration, the analysis identified nickel as a critical element. It is responsible for more than $50 \%$ of the energy and environmental impacts, with few exceptions (ozone depletion and human toxicity-cancer effect). In particular, it causes more than $91 \%$ of the impact on resource depletion. A second design option comes from this result: the supply chain of nickel has to be examined in detail in order to identify the environmental hot spots and to find reliable alternatives for making the nickel supply more sustainable from an environmental point of view. Furthermore, future strategies will promote the use of secondary nickel obtained from exhaust batteries. This proposed eco-design option is expected to have positive effects due to the reduction of the nickel environmental impacts and to the increasing rate of the recycled and circular materials.

Considering that resource consumption is one of the key issues of the circular economy, future eco-design strategies should be oriented toward cell materials, such as nickel, that are largely responsible for resource depletion and other impacts. Focusing on the identified critical element, eco-design options suggested by the above results include the reduction of the amount of nickel in the cell (if possible), and the use of nickel from more sustainable supply chains or nickel recovered from batteries at the end-of-life.

Finally, the application of the LCA methodology for comparison purposes highlighted that when the analysis focuses on different impact categories related to different environmental problems and, often, a "best option" does not exist and researchers have to deal with conflicting domains. However, the LCA results help to select the "best compromise solution" that improves most of the examined impact categories and to identify the critical elements of each examined option to improve the environmental footprint of products. 
Author Contributions: Conceptualization, S.L., F.G., M.F. and N.B.; Methodology, S.L., M.A.C. and M.C.; Software, S.L., M.A.C. and F.G.; Validation, S.L., M.C. and D.P.; Formal Analysis, M.M. and M.C.; Investigation, N.B. and C.D.; Resources, S.L. and M.C.; Data Curation, S.L., S.G.L. and C.D.; Writing-Original Draft Preparation, S.L. and M.C.; Writing-Review and Editing, M.M., M.C., D.P., S.G.L., G.T. and M.F.; Visualization, M.M. and M.C.; Supervision, M.C., V.A. and M.F.; Project Administration, V.A. and M.F.; Funding Acquisition, V.A. and M.F. All authors have read and agreed to the published version of the manuscript.

Funding: This research was funded by the Italian Ministry of Economic Development in the framework of the "Fondo per la Ricerca di Sistema Elettrico-Piano Triennale 2019-2021—Progetto Sistemi Elettrochimici per l'accumulo di energia".

Institutional Review Board Statement: Not applicable.

Informed Consent Statement: Not applicable.

Conflicts of Interest: The authors declare no conflict of interest.

\section{References}

1. European Environment Agency. Circular by Design—Products in the Circular Economy, EEA Report No 6/2017; European Environment Agency: Copenhagen, Denmark, 2017; ISBN 1977-8449.

2. Ardente, F.; Beccali, G.; Cellura, M. Eco-sustainable energy and environmental strategies in design for recycling: The software "ENDLESS". Ecol. Model. 2003, 163, 101-118. [CrossRef]

3. European Commission. Communication from the Commission to the European Parliament, the Council, the European Economic and Social Committee and the Committee of the Regions "A new Circular Economy Action Plan for a Cleaner and More Competitive Europe" $\operatorname{COM(2020)} 98$ Final; European Commission: Brussles, Belgium, 2020.

4. European Union. Directive 2006/66/EC of the European Parliament and of the Council of on batteries and accumulators and waste batteries and accumulators and repealing Directive 91/157/EEC. Off. J. Eur. Union 2006, 266, 1-14.

5. European Battery Alliance. Priority Actions. Available online: www.eba250.com (accessed on 26 January 2021).

6. European Commission. Report from the Commission to the European Parliament, the Council, the European Economic and Social Committee, the Committee of the Regions and the European Investment Bank on the Implementation of the Strategic Action Plan on Batteries: Building a Straegic Battery Value Chain in Europe; European Commission: Brussels, Belgium, 2019.

7. Guarino, F.; Cassarà, P.; Longo, S.; Cellura, M.; Ferro, E. Load match optimisation of a residential building case study: A cross-entropy based electricity storage sizing algorithm. Appl. Energy 2015, 154, 380-391. [CrossRef]

8. European Union. Directive 2009/125/EC of the European Parliament and of the Council of establishing a framework for the setting of ecodesign requirements for energy-related products (recast). Off. J. Eur. Union 2009, 285, 10.

9. Cusenza, M.A.; Guarino, F.; Longo, S.; Ferraro, M.; Cellura, M. Energy and environmental benefits of circular economy strategies: The case study of reusing used batteries from electric vehicles. J. Energy Storage 2019, 25, 100845. [CrossRef]

10. UNI EN ISO 14040. 'Environmental Management—Life Cycle Assessment-Principles and Framework'. July 2006. Available online: https: / www.iso.org/standard/37456.html (accessed on 26 January 2021).

11. UNI EN ISO 14044. 'Environmental Management-Life Cycle Assessment-Requirements and Guidelines'. July 2006. Available online: https:/ / www.iso.org/standard/38498.html (accessed on 26 January 2021).

12. Cusenza, M.A.; Bobba, S.; Ardente, F.; Cellura, M.; Di Persio, F. Energy and environmental assessment of a traction lithiumion battery pack for plug-in hybrid electric vehicles. J. Clean. Prod. 2019, 215, 634-649. [CrossRef]

13. Longo, S.; Antonucci, V.; Cellura, M.; Ferraro, M. Life cycle assessment of storage systems: The case study of a sodium/nickel chloride battery. J. Clean. Prod. 2014, 85, 337-346. [CrossRef]

14. Sullivan, J.L.; Gaines, L. A Review of Battery Life-cycle Analysis: State of Knowledge and Critical Needs. ANL/ESD/10-7. Argonne National Laboratory e Energy Systems Division. 2010. Available online: http:/ / www.osti.gov (accessed on 19 November 2020).

15. McManus, M. Environmental consequences of the use of batteries in low carbon systems: The impact of battery production. Appl. Energy 2012, 93, 288-295. [CrossRef]

16. Schexnayder, S.M.; Das, S.; Dhingra, R.; Overly, J.G.; Tonn, B.E.; Peretz, J.H.; Waidley, G.; Davis, G.A. Environmental Evaluation of New Generation Vehicles and Vehicle Components. ORNL/TM-2001-266. Available online: http://wwwcta.ornl.gov (accessed on 19 November 2020).

17. Notter, D.A.; Gauch, M.; Widmer, R.; Wager, P.; Stamp, A.; Zah, R.; Althaus, H.J. Contribution of Li-ion batteries to the environmental impact of electric vehicles, Environ. Sci. Technol. 2010, 44, 6550-6556. [CrossRef] [PubMed]

18. Ellingsen, L.A.-W.; Hung, C.R.; Strømman, A.H. Identifying key assumptions and differences in life cycle assessment studies of lithium-ion traction batteries with focus on greenhouse gas emissions. Transp. Res. Part D Transp. Environ. 2017, 55, 82-90. [CrossRef]

19. Majeau-Bettez, G.; Hawkins, T.R.; Strømman, A.H. Life Cycle Environmental Assessment of Lithium-Ion and Nickel Metal Hydride Batteries for Plug-In Hybrid and Battery Electric Vehicles. Environ. Sci. Technol. 2011, 45, 4548-4554. [CrossRef] [PubMed] 
20. Manzoni, R.; Metzger, M.; Crugnola, G. ZEBRA Electric Energy Storage System: From RED to Market; HTE hi.tech.expo: Milan, Italy, 2008; pp. 25-58.

21. Sudworth, J. The sodium/nickel chloride (ZEBRA) battery. J. Power Sources 2001, 100, 149-163. [CrossRef]

22. Parkhided, B. Project: Storage Technologies for Hybrid Electric Buses, Subject: ZEBRA Battery, 2nd ed.; Electrochemical Energy Conversion and Storage Systems Group, RWTH Aachen University: Aachen, Germany, 2006; Available online: http://www. euromatic.no/ZEBRA_Aug17.pdf (accessed on 19 November 2020).

23. Matheys, J.; Van Autenboer, W.; Van Mierlo, J. SUBAT: Sustainable Batteries—Work Package 5: Overall Assessment. Final Public Report; Vrije Universiteit Brussel and ETEC: Brussel, Belgium, 2004.

24. Matheys, J.; Timmermans, J.M.; Van Autenboer, W.; Van Mierlo, J.; Maggetto, G.; Meyer, S.; De Groof, A.; Hecq, W.; Van den Bossche, P. Comparison of the Environmental impact of 5 Electric Vehicle Battery technologies using LCA. In Proceedings of the LCE 2006, Leuven, Belgium, 31 May-2 June 2006.

25. Li, G.; Lu, X.; Kim, J.Y.; Meinhardt, K.D.; Chang, H.J.; Canfield, N.L.; Sprenkle, V.L. Advanced intermediate temperature sodium-nickel chloride batteries with ultra-high energy density. Nat. Commun. 2016, 7, 10683. [CrossRef] [PubMed]

26. Lu, X.; Coffey, G.; Meinhardt, K.; Sprenkle, V.; Yang, Z.; Lemmon, J.P. Lemmon, High Power Planar Sodium-Nickel Chloride Battery. ECS Trans. 2010, 28,7-13. [CrossRef]

27. Lu, X.; Li, G.; Kim, J.Y.; Lemmon, J.P.; Sprenkle, V.L.; Yang, Z. The effects of temperature on the electrochemical performance of sodium-nickel chloride batteries. J. Power Sources 2012, 215, 288-295. [CrossRef]

28. Kim, S.-M.; Lee, S.-M.; Jung, K.; Park, Y.-C.; Cho, N.-U.; Kim, H.-S. Feasibility Study of a Planar-type Sodium-Nickel Chloride Battery. Bull. Korean Chem. Soc. 2016, 37, 695-699. [CrossRef]

29. Kirchev, A. Battery management and battery diagnostics. In Electrochemical Energy Storage for Renewable Sources and Grid Balancing; Moseley, P.T., Garche, J., Eds.; Elsevier: Amsterdam, The Netherlands, 2015; pp. 411-435.

30. Pilla, P.; Mehta, H.D. Basic Electrical Engineering; S. Chand Publishing: New Delhi, India, 2012.

31. Li, G.; Lu, X.; Kim, J.Y.; Lemmon, J.P.; Sprenkle, V.L. Cell degradation of a Na-NiCl2 (ZEBRA) battery. J. Mater. Chem. A 2013, 1 , 14935. [CrossRef]

32. Sessa, S.D.; Crugnola, G.; Todeschini, M.; Zin, S.; Benato, R. Sodium nickel chloride battery steady-state regime model for stationary electrical energy storage, J. Energy Storage 2016, 6, 105-115. [CrossRef]

33. Frischknecht, R.; Jungbluth, N.; Althaus, H.-J.; Bauer, C.; Doka, G.; Dones, R.; Hischier, R.; Hellweg, S.; Humbert, S.; Köllner, T. Implementation of Life Cycle Impact Assessment Methods. 2007. Available online: https:/ /www.ecoinvent.org/ (accessed on 19 November 2020).

34. European Commission-Joint Research Centre. Characterisation Factors of the ILCD Recommended Life Cycle Impact Assessment Methods: Database and Supporting Information; European Commission: Rome, Italy, 2012.

35. Wernet, G.; Bauer, C.; Steubing, B.; Reinhard, J.; Moreno-Ruiz, E.; Weidema, B.P. The ecoinvent database version 3 (part I): Overview and methodology. Int. J. Life Cycle Assess. 2016, 21, 1218-1230. [CrossRef]

36. Rabah, M.; Farghaly, F.; Motaleb, M.A.-E. Recovery of nickel, cobalt and some salts from spent Ni-MH batteries. Waste Manag. 2008, 28, 1159-1167. [CrossRef] [PubMed]

37. European Commission. Commission Staff Working Document Report on Raw Materials for Battery Applications, SWD (2018) 245/2 Final; European Commission: Brussels, Belgium, 2018. 